
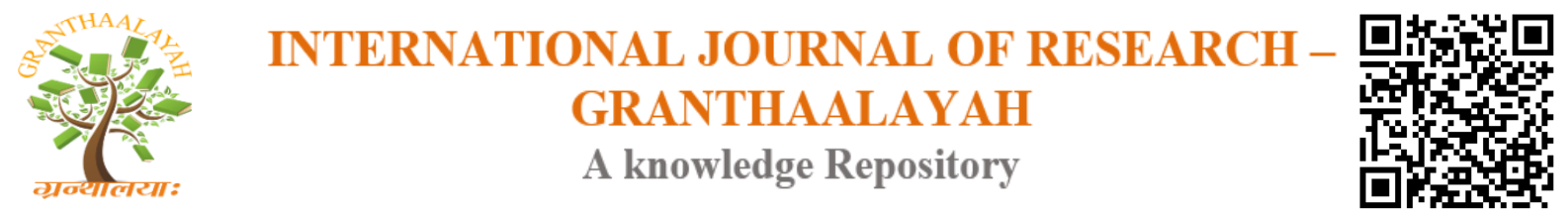

Management

\title{
A STUDY ON JOB STRESS AMONG PRIVATE HOSPITALS EMPLOYEES IN THENI DISTRICT
}

\author{
Dr.J.Mohamed Ali ${ }^{1}$, Mrs.N.Thahira ${ }^{2}$ \\ ${ }^{1}$ Assistant Professor \& Ph.D., Research Advisor in Commerce, Khadir Mohideen College, \\ Adirampattinam, India \\ ${ }^{2}$ Research Scholar in Commerce, Khadir Mohideen College, Adirampattinam - 614 701, \\ Thanjavur District, Tamil Nadu, India
}

\begin{abstract}
Human resource management is an art of managing people at a work in such manner that they give their best to their organization. In simple word HRM refers to the quantitative aspects of employees working in an organization. Stress is a part of day-to-day living of every individual. We generally believe that the stress is caused by the external events and the dynamics of the environment. But we need to emphasis the fact that the Stress is caused by our reaction to the external environment.

Keywords: Human Resource Management; Stress; Attributes and Causes of Stress and Problems.

Cite This Article: Dr.J.Mohamed Ali, and Mrs.N.Thahira. (2017). "A STUDY ON JOB STRESS AMONG PRIVATE HOSPITALS EMPLOYEES IN THENI DISTRICT.” International Journal of Research - Granthaalayah, 5(7:SE), 48-55. 10.29121/granthaalayah.v5.i7(SE).2017.2046.
\end{abstract}

\section{Introduction}

Human resource management is an art of managing people at a work in such manner that they give their best to their organization. In simple word HRM refers to the quantitative aspects of employees working in an organization.

Organizations are not mere bricks, mortar, machineries or inventories. They are people, who staff manage and organizations. HRM involves the applications of management functions and principles. The functions and principles are applied to acquisitioning, developing, maintain and remunerating employees in an organization.

Stress is a part of day-to-day living of every individual. We generally believe that the stress is caused by the external events and the dynamics of the environment. But we need to emphasis the fact that the Stress is caused by our reaction to the external environment. The manner in which we perceive and understand the changes or the particular event creates same event can bring happiness and cause. Hans Selye was one of the founding fathers of stress research. His view in 
1956 was that "stress is not necessarily something bad - it all depends on how you take it. The stress of exhilarating, creative successful work is beneficial, while that of failure, humiliation or infection is detrimental." Selye believed that the biochemical effects of stress would be experienced irrespective of whether the situation was positive or negative.

\section{Sources of Stress}

The Environment: The natural stressors, for example, climate, commotion, swarming, contamination, movement, perilous and substandard lodging, and wrongdoing.

Social Stressors: Social stressors, for example, due dates, monetary issues, prospective employee meetings, presentations, differences, requests for your time and consideration, loss of a friend or family member, separation, and co-child rearing. These stressors emerging because of requests of the diverse social parts, for example, guardian, life partner, parental figure, and worker.

Physiological: Physiological stressors incorporate fast development of puberty, menopause, disease, maturing, conceiving an offspring, mishaps, absence of activity, poor sustenance, and rest aggravations.

Contemplations: Human cerebrum translates and sees circumstances as upsetting, troublesome, difficult or wonderful, in such circumstance our mind figures out if they are issues to us or not.

\section{Review of Literature}

Employee turnover is an employee's voluntary withdrawal from the organization.1 High turnover has been a major issue in health-care organizations. Turnover of skilled staff can incur substantial costs (e.g. costs associated with recruiting and training new staff) for organizations. High staff turnover can also impact negatively on an organization's capacity to meet patient needs and provide quality care. 2 Turnover intention is a determinant of actual turnover behaviour. Turnover intention and turnover decisions may be an indicator of low, and decreased QWL.3

Some studies found a positive relationship between employees' QWL and their job satisfaction4 and organizational commitment. 5 Low employees' job satisfaction is a significant predictor of their turnover intention and actual turnover.6 Other empirical studies confirm the important role of organizational commitment in the turnover process. 7

On the other hand, a strong inverse relationship was found between employees' job stress and their job satisfaction. 8 Job stress also may lead to increased burnout.9 In addition, some studies found a relationship between employees' job stress and their organizational commitment10 and intentions to leave their workplaces. 11

Darshan et al (2009)12 in their article, A study on professional stress, depression and alcohol use among Indian software professionals, observed that the software employees are professionally stressed and are at 10 times higher risk for developing depression and also significantly increase the incidence of psychiatric disorders. Preventive strategies like training in stress management, frequent screening to identify professional stress and depression at the initial stages and 
addressing these issues adequately might help the software professionals cope with their profession better without affecting their lifestyle and health.

Saurabh Shrivastava and Prateek Bobhate (2010)13 in their study, Computer related health problems among software professionals in Mumbai: A cross-sectional study, investigated that Ocular discomfort, musculo-skeletal disorders and psycho-social problems form key category of health problems found among constant computer users. This study has also brought into focus factors contributing to the occurrence of these problems. Thus, the problem requires a multidisciplinary action and hence there is an immediate need for the concerned authorities to collaborate and enforce suitable preventive measures.

Jakkula Rao and Chandraiah (2011)14 in their article, Occupational stress, mental health and coping among information technology professionals, found that job satisfaction and mental health are correlated but not significant. However, job satisfaction was positively and significantly correlated with coping behaviour. The mental health is negatively and significantly correlated with occupational stress. It can be explained that as job satisfaction and mental health increases coping behavior increases. And as stress increases mental health decreases.

Kesavachandran et al (2012)15 in their study, Working conditions and health among employees at information technology - enabled services: A review of current evidence, identified that musculo-skeletal disorders, ocular disorders and psycho-social problems were some of the key health problems observed among software professionals. There is a need for implementation of the programs that include the concepts of ergonomics, health education, training of personnel to prevent and overcome the morbidity, as well as psycho-social problems among workers in software industry.

\section{Objectives of the Study}

1) To analyze the level occupational stress among the private hospital employees in Theni District

2) To examine the causes of stress in the study area

3) To study the methods and techniques applied for stress of the hospitals employees.

4) To offer suggestions based on the findings.

\section{Data Analysis and Interpretations}

The study depends up on the primary and secondary data. Primary data were collected by conducting a sample survey o employees working in Theni district. There are 100 staff members of private hospitals employees have been randomly selected for the present study. Stratified random sampling technique has been used for this study. A well-conceived questionnaire was used for the collection primary data. The secondary data was collected from research publications, standard journals and periodicals, books, websites, etc., this paper is also analysis of data collection by representing it in tabular form along with interpretations. The information collected and analysed for arriving at proper conclusion of the study. 
Table 1: Sample size the respondents

\begin{tabular}{|l|l|l|l|}
\hline S.No. & Designation & No. of respondents & Percentage \\
\hline 1 & Doctors & 15 & 15 \\
\hline 2 & Nurses & 25 & 25 \\
\hline 3 & Supervisors & 15 & 15 \\
\hline 4 & Lab Technicians & 10 & 10 \\
\hline 6 & Receptionists & 10 & 10 \\
\hline 7 & Compounders & 10 & 10 \\
\hline 8 & Room boys / servants & 15 & 15 \\
\hline & Total & 100 & 100 \\
\hline
\end{tabular}

Source: Primary data

From the table 1 shows that the majority of the respondents working in stressed. Among the total respondents $25 \%$ of them come from Nurses, $15 \%$ each of them doctors, supervisors and room boys or servants. It is clearly show the above table.

Table 2: Causes of stress

\begin{tabular}{|l|l|l|l|}
\hline S.No. & & No. of respondents & Percentage \\
\hline 1 & Role conflict & 13 & 13 \\
\hline 2 & Role ambiguity & 04 & 04 \\
\hline 3 & Excess of work load & 25 & 25 \\
\hline 4 & Feeling of inequality & 06 & 06 \\
\hline 5 & Lack of supervisory support & 12 & 12 \\
\hline 6 & Constraints of changes rules and regulations & 02 & 02 \\
\hline 7 & Stress due to technological problems & 20 & 20 \\
\hline 8 & Inadequacy of role & 04 & 04 \\
\hline 9 & Lack of group authority cohesiveness & 02 & 02 \\
\hline 10 & Job requirements capability mismatch & 12 & 12 \\
\hline & Total & 100 & 100 \\
\hline
\end{tabular}

Source: Primary data

Table 2 indicates that major causes of stress among the employees are excess of work load (25\%) and stress due to technological problems (20\%). Hence it was found that employees felt that taking severe work pressure, as they were expecte $4 \mathrm{~d}$ to handle multiple roles and responsibilities the employees suffer from stress because of lack of support from the management and colleagues.

Table 3: Various attributes of stress

\begin{tabular}{|l|l|l|l|}
\hline SNo. & Attributes & No. of respondents & $\%$ \\
\hline 1 & Inadequate time to finish work & 20 & 20 \\
\hline 2 & No ability and skills & 04 & 04 \\
\hline 3 & Hard work and skill are not approved & 02 & 02 \\
\hline 4 & Poor infrastructure facilities & 06 & 06 \\
\hline 5 & Unhealthy environment & 06 & 06 \\
\hline 6 & Communication gap & 18 & 18 \\
\hline
\end{tabular}




\begin{tabular}{|l|l|l|l|}
\hline 7 & Work life imbalance & 40 & 40 \\
\hline 8 & Economic status & 04 & 04 \\
\hline & Total & 100 & 100 \\
\hline
\end{tabular}

Source: Primary data

Table 3 depicted that the various attributes relates to stress, work life imbalance is one of the major attributes which contributes to stress from employee and followed by inadequate time to finish work. This can be regarded as a factor building of stress because a lot of employee complained that they were unable to balance both the personal and professional fronts successfully. Extra more pressures and demands from work environment at times led to neglect of personal front.

Table 4: Stress level of private hospitals employees

\begin{tabular}{|l|l|l|l|}
\hline SNo. & Attributes & No. of respondents & $\%$ \\
\hline 1 & Good environment & 18 & 18 \\
\hline 2 & Recognition & 23 & 23 \\
\hline 3 & Continuous job training & 10 & 10 \\
\hline 4 & Effective communication & 11 & 11 \\
\hline 5 & Programme on stress management & 12 & 12 \\
\hline 6 & Meditation & 26 & 26 \\
\hline & Total & 100 & 100 \\
\hline
\end{tabular}

Source: Primary data

Table 4 reveals that the meditation from an integral part of the science of yoga has a direct positive impact on the mind giving it strength and power to resist stress. Moreover, around ( $23 \%$ ) of the respondents as a acknowledging people's value is especially important in times of stress the above analysis the initiatives taken by the banks to reduce stress are by providing good environment continuous job training proper commutate and conducting effective stress management programmes.

Table 5: Analysis of psychological problems

\begin{tabular}{|l|l|l|l|}
\hline SNo. & Psychological problems & No. of respondents & \% \\
\hline 1 & Anxiety & 24 & 24 \\
\hline 2 & Tension & 22 & 22 \\
\hline 3 & Sleeplessness & 16 & 16 \\
\hline 4 & Boredom & 10 & 10 \\
\hline 5 & Frustration & 12 & 12 \\
\hline 6 & Depression & 06 & 06 \\
\hline 7 & Fear & 04 & 04 \\
\hline 8 & Forget fullness & 06 & 06 \\
\hline & Total & 100 & 100 \\
\hline
\end{tabular}

Table 5 shows that majority of the respondents psychologically affects stress on anxiety and tension (24\% \& 22\%). $4 \%$ of them affected fear, but in the case of $6 \%$ of the respondents affected due to forget fullness in the study area. 


\section{Findings of the Study}

- The majority of the respondents working in stressed. Among the total respondents $25 \%$ of them come from Nurses, $15 \%$ each of them doctors, supervisors and room boys or servants. It is clearly show the above table.

- Major causes of stress among the employees are excess of work load( 25\%) and stress due to technological problems $(20 \%)$. Hence it was found that employees felt that taking severe work pressure, as they were expecte $4 \mathrm{~d}$ to handle multiple roles and responsibilities the employees suffer from stress because of lack of support from the management and colleagues.

- The various attributes relates to stress, work life imbalance is one of the major attributes which contributes to stress from employee and followed by inadequate time to finish work. This can be regarded as a factor building of stress because a lot of employee complained that they were unable to balance both the personal and professional fronts successfully. Extra more pressures and demands from work environment at times led to neglect of personal front.

- The meditation from an integral part of the science of yoga has a direct positive impact on the mind giving it strength and power to resist stress. Moreover, around (23\%) of the respondents as a acknowledging people's value is especially important in times of stress the above analysis the initiatives taken by the banks to reduce stress are by providing good environment continuous job training proper commutate and conducting effective stress management programmes

- A great majority of the respondents psychologically affects stress on anxiety and tension $(24 \% \& 22 \%) .4 \%$ of them affected fear, but in the case of $6 \%$ of the respondents affected due to forget fullness in the study area.

\section{Suggestions}

- Work should be properly delegated to the employees to avoid overload of work which could cause stress. Many tasks can be delegated to subordinates without losing effectiveness so that overload of work can be reduced

- Good relationship should be maintained within the employees to make the working environment healthy.

- Proper grievance handling system should be practiced to help the employees to overcome their problems.

- Employees should be motivated by giving rewards for their excellent performances. The motivation program conducted by the organization will assist the employees to perform well.

- Meditation, yoga, exercises on a daily routine basis will keep the mind and body fresh.

\section{Conclusion}

Stress is a slow and insidious malady which is an unavoidable one and a common problem in the workplace. The level of stress and its amount of consequences vary within and between hospitals based on the nature and type of work practices. Hospitals must begin to manage people at work differently, treating them with respect and valuing their contribution. Recognition, participation 
and continuous training of employees are required to retain the skilled employees. It is the responsibility of the private hospital's organization to see that its employees undergo stress relaxation practices to overcome hospitals employees' stress which maintains the sound health of the employees.

\section{References}

[1] Gray AM, Phillips VL. Labour turnover in the British National Health Service: a local labour market analysis. Health Policy 1996;36:273- 89

[2] Cartledge S. Factors influencing the turnover of intensive care nurses. Intensive and Critical Care Nursing 2001;17:348-55

[3] Gray P. Mental Health in the Workplace: Tackling the Effects of Stress, Mental Health Foundation, London, 2000.

[4] House JS. Work stress and social support. Reading, MA: Addison-Wesley; 1981.

[5] Jones, J. W. \& Boye, M. W. (1992) Job stress and employee counter productivity. In J. Quick, L. Murphy, J. Hurrell, Jr. Eds.) Stress and well-being at work. Washington, DC: American Psychological Association. Northwestern National Life Insurance C.

[6] C. Ross, Improving workplace health one leader at a time, RCMP Gazette, vol. 72, no. 1, pp. 7-9, 2010

[7] Hart, P.M. and C. Cooper, 2001. Occupational Stress: Toward a More Integrated Framework, Handbook of Industrial, Work and Organizational Psychol.,

[8] Stephen P. Robbins and Seema Sanghi (Eleventh edition) - Organizational Behaviour 6. National Institute for Occupational Safety and Health. Stress at work. DHHS (NIOSH) Publication No. 99101.

[9] Golden, S. A. R. (2011). Strategy For Success Of Human Beings:-Time Management. Department Of BBA, St. Joseph's College, Trichy, 388(390), 0.

[10] Regi, S. B., \& Golden, S. A. R. (2014). A Descriptive Study On The Role Of Consumer Psychology And Behaviour In Product Purchasing. Indian Streams Research Journal, 3 (12), 1, 6.

[11] Golden, S. A. R. (2011). An Analysis Of Mental Stress In Heavy Alloy Penetrator Project, Tiruchirappalli. SELP Journal of Social Science, 13.

[12] Shields MA, Ward M. Improving nurse retention in the National Health Service in England: the impact of job satisfaction on intentions to quit. J Health Econ 2001;20:677-701

[13] Golden, S. A. R. (2017). Recent Research in Social Sciences \& Humanities. EduPedia Publications (P) Ltd.

[14] Efraty D, Sirgy MJ. The effects of quality of working life on employee behavioral responses. Soc Indicators Res 1990;22:31-47

[15] Daud N. Investigating the Relationship between Quality of Work Life and Organizational Commitment amongst Employees in Malaysian Firms. Interactional Journal of Business and Management 2010;5:75-82

[16] Griffeth R, Hom P, Gaertner S. A meta-analysis of antecedents and correlates of employee turnover: update, moderator tests, and research implications for the next millennium. J Manag 2000;26:463- 88

[17] Mosadeghrad AM, Ferlie E, Rosenberg D. A study of relationship between job satisfaction, organizational commitment and turnover intention among hospital employees. Health Serv Manag Res 2008;21:211-27

[18] Flanagan NA, Flanagan TJ. An analysis of the relationship between job satisfaction and job stress in correctional nurses. Res Nurs Health 2002;25:282-94

[19] Chou-Kang C, Chi-Sheng C, Chieh-Peng L, Ching Yun H. Understanding hospital employee job stress and turnover intentions in a practical setting: the moderating role of locus of control. $\mathrm{J}$ Manag Dev 2005;24:837-55 
[20] Khatibi A, Asadi H, Hamidi M. The relationship between job stress and organizational commitment in National Olympic and Paralympic Academy. World J Sport Sci 2009;2:272-8 